\title{
TREATMENT OF NAMES IN ZAMBIA AND ESTONIA: A COMPARATIVE ANALYSIS
}

\author{
Osward Chanda ${ }^{1,2}$ and Peeter Päll ${ }^{2}$ \\ ${ }^{1}$ Central European University and the ${ }^{2}$ Institute of the Estonian \\ Language, Tallinn
}

\begin{abstract}
Names constitute a key component of the cultural heritage of any region. Though geographically, culturally and linguistically apart, Estonia and Zambia share some elements and motivations in naming. Zambia's British colonial experience and Estonia's Danish, German, Polish, Swedish and Russian/Soviet influence in the past made significant changes to personal and place names in both regions. Following independence, both states made strides in the indigenisation of names for promoting local heritage and national identity. Zambia predominantly focused on changing the names of some towns, and of the country (from Northern Rhodesia to Zambia). On the other hand, the Estonian onomastic experience has been more comprehensive - regulating both personal and place names, enacting corresponding laws and maintaining the Institute of the Estonian Language to oversee language and name planning, among other responsibilities.
\end{abstract}

Keywords: onomastics, names, names treatment, Zambia, Estonia

DOI: https://doi.org/10.12697/jeful.2020.11.1.10

\section{Overview of the current situation}

Human life would be chaotic and limited without names. Names organise humans as well as help humans to organise their world. This work is a comparative analysis of the treatment of names in Zambia and Estonia. It examines the state of personal names and place names in both countries and drafts suggestions for consideration by the respective authorities.

\subsection{Zambia}

To begin with, Zambia is a multilingual nation. Formerly named Northern Rhodesia in honour of the British governor of the Cape 
Province and proprietor of the British South Africa (BSA) company, Cecil John Rhodes, Zambia has a heritage of seventy-three languages and dialects. These languages have been further condensed into eight national languages, including Bemba, Kaonde, Lozi, Lunda, Luvale, Nyanja, Tonga and Zambian Sign Language. English is the official language. Table 1 below shows the language distribution from the latest national census conducted in 2010 .

Table 1. Major Languages in Zambia. Source: 2010 Census Report, Central Statistical Office [edited - "Others" row added]1. The numbers in the table represent the percentages of total population

\begin{tabular}{lrrr}
\hline Language Group & 1990 & 2000 & 2010 \\
\hline Bemba & 39.9 & 38.5 & 41.0 \\
Nyanja & 20.1 & 20.6 & 23.3 \\
Tonga & 14.8 & 13.9 & 14.5 \\
North Western [Kaonde, Lunda, Luvale] & 8.8 & 7.7 & 6.6 \\
Barotse [Lozi] & 7.5 & 6.9 & 6.3 \\
Others & 9.9 & 12.4 & 9.3 \\
\hline
\end{tabular}

As is the practice in other countries, Zambians generally draw their personal names from a wide selection of languages including the local and foreign languages. It is worth noting, however, that as much as seventy percent of forenames in Zambia are drawn from the foreign languages, especially European languages. Surnames, on the other hand, are almost always drawn from the local languages. ${ }^{2}$ In all, people are free to use proper names from any language or even invent new names for their children or for themselves.

Importantly, prior to the region's contact with Europeans, which became predominant from the mid-nineteenth century onward, persons usually had only one name. To further distinguish an individual,

Central Statistical Office. "Zambia 2010 census of population and housing national analytical report 2010"' (Government of Zambia) Available online at $<\mathrm{https}$ ://www.zamstats.gov.zm/phocadownload/2010_Census/2010\%20Census\%20of\%20Population $\% 20$ National\%20Analytical\%20Report.pdf>. Accessed on 7.05.2019.

2 Results of personal research 2017 (unpublished). 13,000 names were surveyed from the publicly available school enrolment registers in Lusaka and Copperbelt provinces. See also Tembo 2006. 
reference was made to that individual's mother's or father's totem name in matrilineal or patrilineal communities, respectively (Ngulube 1989, Lisimba 2000 and Kapwepwe 2002). Most ethnic groups in Zambia are inclined toward the matrilineal (Ngulube 1989). For instance, if there were several persons with the name Mulenga, they would be distinguished as Mulenga umwina Lungu or Mulenga of the Lungu (clan), Mulenga of the Besa, Mulenga of the Mwansa, and so on. Other forms of distinction would be based on the village name or other features such as personality, appearance, personal accomplishments, and so on.

Similarly, the semantically transparent prefix mwana in the patrilineal Lozi culture denoting the phrase 'child' or 'child of', is also found among other cultures - both matrilineal and patrilineal - with the same meaning in many Zambian languages. In many cases, the expression mwana represents clan/totem names. Examples of its usage include: Mwanamwambwa (lit. 'child of' Mwambwa - Lozi), Mwanambinyi (Lozi), Mwanamuke (Lozi), Mwanamungu (Lozi), Mwanamwalye (Lozi), Mwanang'uku (Lozi), Mwanawasa (Lenje), Mwanakatwe (Bemba), Mwanalesa (Bemba), Mwanachingwala (Tonga) and so on. Following the European contact through Christian missionary work and colonisation, many clan names in Zambia became the basis of surnames which are also currently in use.

There is no law that governs naming, except the National Registration Act (NRAZ) and the Deed Poll. The former introduced a requirement for nationals who attain the age of 16 to acquire a national registration card (NRC) and attainment of age 18 as a prerequisite to the acquisition of a passport. The Deed Poll provides guidance on name change. In practice, name change is difficult in Zambia. As there are no detailed guidelines concerning the procedure, an official can simply decline an application to change a name - as some cases have revealed. ${ }^{3}$

In relation to place names, Zambia is mostly characterised by one set of official names, with the exception of the Victoria Falls (Mosi-OTunya, Shungu Namutitima), Luapula River (Lualaba - name used in neighbouring Congo DR), Western Province (Barotseland, Kwa Hae) and probably a few other places. It is also common in Zambia to use personal names and commercial names as place names. The use of personal names is, perhaps, a legacy linked to the colonial heritage.

Personal experience. 
Many places were named after British administrators and other outstanding personalities in the British empire. Examples include: Abercorn (currently Mbala), Bancroft (Chililabombwe), Feira (Luangwa), Fort Jameson (Chipata), Fort Rosebery (Mansa), Johnston Falls (Mumbuluma Falls), Livingstone (name still maintained), Rhodespark (name still maintained), Victoria Falls (name still maintained) and so on. (Chanda 2019)

Similarly, after independence in 1964, and presently, names of Zambian and other African leaders, including living persons, are also commonly used as place names. As an exception, current naming of places in Zambia after persons from outside the African continent has seen an entire new neighbourhood and an old road named after the former US President Barack Obama in Lusaka.

Furthermore, commercial names such as the names of shops, industries, and other entities often become place names. The reason for this disorder is often the absence of a naming system. Lack of regulation brings disorder in the Zambian case. Bus stops, for instance, may take on the names of nearby businesses. These become rooted as place names. Examples of commercial names which have become names of bus stops include Doctor $W u$ (the name of a Chinese clinic), ZESCO (Zambia Electricity Supply Corporation), Mandahill (a shopping mall), Arcades (a shopping mall), Shokaz (a grocery shop), Katungu (a shop).

The closest that Zambia has come to the standardization of geographical names on a more comprehensive scale was the publication of the Gazetteer of Geographical Names in the Republic of Zambia by the Ministry of Lands and Mines (1966). About 35,000 place names were published, alongside their coordinates. Aganyo (1991) referred to the efforts by the Zambian government to raise this record to 45,000 names. He, however, cited the lack of resources as a major impediment to progress in this endeavour.

It is worth noting that there have been significant changes in the number of districts - from 72 to 118 , and a tenth province has been recently created. This is part of the effort to decentralise development by the current government since 2011. As a result, many populated places have been turned into districts. 


\subsection{Estonia}

Estonia, on the other hand, is officially monolingual, Estonian being the official language. By ethnic composition, Estonians (68.5\%), Russians (24.8\%), Ukrainians (1.8\%), Belarusians (0.9\%) and Finns $(0.6 \%)$ constitute the largest groups. ${ }^{4}$ Besides Estonian, Russian and English are more used languages in the media, business and public information.

Personal names of Estonians can be characterized as heterogeneous. According to the population register, there are more than 50,000 different forenames in use ${ }^{5}$ and about 146,000 different surnames ${ }^{6}$. There is no statistics available on how many forenames could be considered as being 'purely' Estonian linguistically but it has been generally admitted that increasingly the tendency is to use 'internationally' recognized names. For 2018, the top 5 names of boys were Robin, Oliver, Rasmus, Mattias and Sebastian, of girls Sofia, Mia, Lenna, Maria and Emma (Blog, Statistics Estonia). To a certain degree, this tendency can also be observed in the naming preferences of Russians, the largest minority group in Estonia. Regarding surnames, it was estimated in the 1930s, prior to the campaign to Estonianize names, that more than a half of surnames had a foreign-language origin (Hussar and Päll 2007: 179). The bulk of surnames were given to Estonians in 1822-1834 at the time when the influence of German-speaking manor owners and pastors was still strong.

Estonia has a Names Act which was adopted in 2004 and then amended several times (NA 2004). It includes detailed regulations on giving forenames and surnames to children, obtaining surnames by marriage and divorce, grounds for changing names, etc. It also determines orthographic requirements, e.g. a given name must conform to the spelling rules, a foreign-language name must be proved to be in use

4 Based on the data of 1 January 2019 (Statistics Estonia at <https://www.stat.ee/34267>, accessed on 05.09.2019). Other more numerous groups include (in the declining order) Latvians, Germans, Lithuanians, Tatars, Jews, Poles, Armenians and Azerbaijanis. For $1.3 \%$ of the whole population, the ethnic identity is not known.

5 Data of autumn 1995. Forenames consisting of several given names (such as Karl Eduard) are counted separately. Roughly two thirds of the names are unique, occurring only once.

6 Data of 2017. Roughly one third of the names are unique. 
in a foreign country, etc. Currently (2019), a revised draft of the Names Act has been prepared.

Regarding place names, there is at present one main set of names in use, with some exceptions for national minorities, e.g. there are parallel official names for some areas in north-western Estonia where Swedish has been historically used (Pürksi/Birkas, Osmussaar/Odensholm, etc.) Historically, because of the centuries-long foreign domination, Estonia has had a multilingual set of names and there have been distinct German and Russian variants of some place names in use. Other languages in which place names have been recorded include Latin, Low German, Danish, Polish and Swedish (see EKNR 2016: 15-16 for examples).

Estonia also has a Place Names Act (PNA 1996), first adopted in 1996, that has two main purposes: to determine the division of the naming power (who has the right to approve official names) and to protect cultural heritage as expressed in place names. In comparison to the Names Act, the Place Names Act is much more stringent when it comes to the language of names; there is a provision that, as a rule, the official place names shall be in Estonian.

\section{Differences and similarities}

Given this background, we could summarize the following differences between Zambia and Estonia that may have an impact on the treatment of names:

1. Estonia has the Names Act (for personal names) and the Place Names Act (for place names), while Zambia has no specific naming regulation.

2. Estonia is mainly monolingual (though some other languages are also widely used) while Zambia is multilingual (though English is the official language).

3. Whereas Zambia is yet to fully digitize and harmonise personal name records, Estonia is widely using digital databases such as the population register. ${ }^{7}$

Although the spelling in different databases should be harmonised: besides the Population Register, there is also a register (mainly for passports) maintained by the Police and Borderguard Department with a much more restricted choice of characters. 
4. While educational instruction, broadcasting services and administrative functions are to a great extent carried out in a foreign language in Zambia, Estonia uses mainly the local language.

But there are, perhaps unexpectedly, also some similarities:

1. History-wise, both Zambia and Estonia have experienced domination by foreign power(s) - in the Zambian case, the colonial power (Britain), in the Estonian case, the neighbouring countries and peoples (Germans, Danes, Poles, Swedes, Russians). All this has left traces in personal naming systems and toponymy, and raised the need to safeguard the autochthonous identity of both countries.

2. In connection with this circumstance, Zambian local languages and Estonian did not have distinct writing systems before foreign domination. This means that personal and place names were initially written down by foreigners, with distortions resulting from the ignorance of the language(s) in question. In the Zambian case, place names such as Mulifulile (transformed to Mufulira), Inkelenge (Nchelenge), Mungu (Mongu), Mupika (Mpika) and many others, were transformed from transparent and historical names to meaningless words by colonial officials. In the Estonian case many historical names recorded in archival documents are difficult to interpret because the writers used spellings conventional to their own languages. We would never know for sure if Wagenküll (modern Taagepera, 1509 Wafenkul, 1620 Wahokill) could correspond to Vaoküla (reconstructed name form used at the end of the 1930s), Vahuküla, Vaeküla or something else (EKNR 2018).

\section{Recognizing some universal principles}

Though it would seem that there are too few similarities between such distant countries as Zambia and Estonia, we try to formulate, based on the previous analysis, some of the universal principles for the treatment of names that could be applied in many countries of the world, perhaps the exception being principle No. 4 as not every country has suffered foreign domination in the past. Some of the principles may apply mostly to place names. It has to be acknowledged that because the pragmatic aspects of names - often e.g. the habitual usage of names - 
might sometimes contradict the heritage or identity aspects, there is also some unavoidable contradictiveness in the principles below and in these cases, prioritization of the principles is needed.

1. Preservation of names as cultural heritage. Names form a part of our intangible heritage as they reflect the history of the people, they give valuable insight into the spiritual world of our ancestors. Place names give testimony to ancient peoples and tribes that have once settled in the areas. The aspect of safeguarding place names as part of cultural heritage has gained much more support recently. At the United Nations Group of Experts on Geographical Names (UNGEGN), a working group was established in 2002 that is known as the Working Group on Geographical Names as Cultural Heritage (UNGEGN website) as of 2012. Increasingly, there are calls for UNESCO to recognize the value of place names.

In the legislation of individual countries, the principle would involve the requirement to safeguard historically valuable names and to prevent arbitrary renaming or the loss of such names.

2. Preference given to actual usage. This is a part of democracy: names cannot be imposed from above or by outsiders but they should reflect the local usage as much as possible. The reasons why official names may differ from the actual local names can be manifold: sometimes because of tradition, but sometimes also for ideological grounds (such as campaigns to promote ideologically 'correct' names during the communist era). One should note that in some cases this principle can conflict with the previous one: namely, when historically valuable names are lost in actual usage.

In legislation, this principle would mean that the officialization of the actual local names should be facilitated.

3. Names should be linguistically correct. This may mean different issues to different people but for clarity it should be emphasized here that regional or dialectal variants of names should also be considered as linguistically correct. Rather, the emphasis should be on avoiding distortions of names. It is recognized that traditions may have an impact here: in Zambia, for example, the spelling of place names came to be established before the spelling of local languages was standardized in 1977 (Kashoki 1981), hence the difference between the official spellings and local pronunciation of names such as Choma vs. Chooma, Kasama vs. Kaasaama, Kitwe vs. Kiitwe or 
Chiitwe, Luanshya vs. Lwaanshya, Luangwa vs. Lwangwa, Monze vs. Moonze (Chanda 2019).

In legislation, it would mean that the questions of spelling must be addressed with due regard to the actual circumstances.

4. Safeguarding one's own cultural identity in names. This could be a controversial principle but it should be observed that protection against excessive foreign influence sometimes has a high symbolic value for the local people. Defending the 'authentic' way of using names and rejecting 'foreign' names can be justified as part of preserving cultural heritage. This should not, perhaps, be imposed from above such as the campaign to Estonianize surnames in the 1930s or the authenticité campaign to Africanize names in former Zaire (present Democratic Republic of Congo). Rather, it would make sense to inform people of the values of traditional naming. Re-introduction of lessons on names in related subjects in elementary and secondary schools could be a good starting point in Zambia, as practised elsewhere (see, e.g. Agabekova 2017, Clark 1972, Harder 1967 and Whiteman 2008), for creating awareness of the value of local names among the young learners. Other complementary efforts in promoting local names include creating a digital database from our Encyclopedia of Zambian Names ${ }^{\mathrm{TM}}$ (Penda 2013) to be accessed on various technological platforms. Corporate efforts by Zambian onomastic scholars would also go a long way in promoting local names.

5. Pragmatic principles of naming. Finally, one should acknowledge that names constitute pragmatic means of identifying people, places and other objects; thus, they should be distinguishable from each other, place names should be standardized according to the recommendations of the United Nations and information on standardized names should be widely disseminated (UNGEGN website).

In legislation, that would also mean that the 'naming powers' (who has the power to officially name any features) and requirements have to be clearly determined.

\section{Conclusion}

Personal and place names constitute an important aspect of personal, family or communal/national heritage. Both Zambian and Estonian 
names have been significantly affected through domination by foreign powers. The lack of name laws in Zambia is the source of a freedom of choice in assigning personal names and a 'disorderliness' in assigning and use of place names. This status quo places national heritage at a disadvantage. On the other hand, there is relatively more order in Estonia regarding the treatment of both personal and place names. This is facilitated, on the one hand, by the Names Act (for personal names) and the Place Names Act and, on the other, by the Institute of the Estonian Language (EKI) and various other government departments which collaborate in the implementation of the legislation on names. Promotion of local names at the national level has immense potential in safeguarding a nation's cultural heritage. Thus, a deliberate effort is necessary in Zambia to promote lessons on local names in related subjects in schools, to enhance collaboration among onomastic scholars and to create orderliness through the introduction of name legislation. In Estonia, it is more important to find the balance between efforts to preserve cultural heritage through names and the individuals' expression of their freedom of choice with regard to personal naming.

\section{Acknowledgements}

This article was written as part of an internship at the Institute of the Estonian Language (EKI) in August 2019.

Notes by Osward Chanda: I immensely appreciate the Central European University (CEU) Budapest Foundation, the Cultural Heritage Studies Program and the Medieval Studies Department at CEU and the Institute of the Estonian Language for their financial support, making it possible for me to pursue my current MA studies, to conduct my field research in Chongwe, Kafue and Lusaka (Zambia), and to do my internship in Tallinn, Estonia. I also thank my supervisors Dr. Eszter Spat (CEU) and Dr. Peeter Päll (EKI) for their patience, commitment and guidance. My gratitude also goes to Mr. Gankhanani Moffat Moyo, coordinator of the new Intangible Cultural Heritage (ICH) undergraduate programme at the University of Zambia for giving me the valuable opportunity to observe his ICH class. In addition, I thank the International Council of Onomastic Sciences (ICOS) for funding the first ever ICOS Summer School and for the privilege given to me to be among the 
first participants. The University of Helsinki also gave me a platform to test and remould my understanding by giving me the opportunity to present my paper at the Personal Names and Cultural Reconstructions conference in Helsinki.

\author{
Addresses: \\ Osward Chanda \\ Central European University \\ Budapest, Hungary \\ E-mail: Chanda_Osward@student.ceu.edu \\ Peeter Päll \\ Institute of the Estonian Language \\ Roosikrantsi 6 \\ 10119 Tallinn \\ E-mail: peeter.pall@eki.ee
}

\title{
References
}

Agabekova, Z. (2017) "Methods of using onomastics in teaching language and culture”. In Global Journal of Sociology: Current Issues 7, 2, 104-109. https://doi.org/10.18844/gjs.v7i2.2395

Aganyo, Joseph R. R. (1991) "Report on the status of standardization of geographical names in Africa East Division". United Nations Group of Experts on Geographical Names. Fifteenth Session. Geneva, 11-19 November 1991. Available online at $<$ https://unstats.un.org/unsd/geoinfo/UNGEGN/docs/15th-gegn-docs/15th_gegn_ WP32.pdf $>$. Accessed on 30.09.2019.

Alhaug, Gulbrand and Minna Saarelma (2017) "Naming of children in Finnish and Finnish-Norwegian Families in Norway". In Terhi Ainiala and Jan-Ola Östman, eds. Socio-onomastics: the pragmatics of names, 70-91. (Pragmatics \& Beyond New Series, 275.) John Benjamins. https://doi.org/10.1075/pbns.275.04alh

Blog, Statistics Estonia. Available online at $<$ https://blog.stat.ee/tag/nimede-statistika/>. Accessed on 05.09.2019.

Central Statistical Office. "2010 Census of Population National Analytical Report.Pdf" (Government of Zambia). Available online at $<$ http://www.zamstats.gov.zm/phocadownload/2010_Census/>. Accessed on 07.05.2019.

Chanda, Osward (2019) Zambia: geographical names. Tallinn: Institute of the Estonian Language. Available online at $<\mathrm{http} / /$ www.eki.ee/knab/valik/zm_inf.htm $>$. Accessed on 27.09.2019. 
Clark, Thomas (1972) "The environment of names in the classroom". Elementary English 49, 7, 1061-1063.

EKNR 2018 = Kallasmaa, Marja, Evar Saar, Peeter Päll, Marje Joalaid, Arvis Kiristaja, Enn Ernits, Mariko Faster, Fred Puss, Tiina Laansalu, Marit Alas, Valdek Pall, Marianne Blomqvist, Marge Kuslap, Anželika Šteingolde, Karl Pajusalu and Urmas Sutrop. Eesti kohanimeraamat (2018). Available online at $<$ http://www.eki.ee/dict/ knr/index.cgi>. Accessed on 22.09.2019.

Harder, Kelsie B. (1967) Place names in the classroom. Available online at $<$ https:// files.eric.ed.gov/fulltext/ED017500.pdf $>$. Accessed on 30.09.2019.

Hussar, Annika and Peeter Päll (2007) "Das estnische Personennamensystem". In Andrea Brendler and Silvio Brendler, eds. Europäische Personennamensysteme. Ein Handbuch von Abasisch bis Zentralladinisch, 170-187. (Lehr- und Hausbücher zur Onomastik, 2.) Hamburg: Baar.

Kapwepwe, Mulenga M. (2002) Some Bemba names and their meanings. Lusaka: Mulenga Kapwepwe.

Kashoki, Mubanga E. (1981) "Harmonization of African languages: standardization of orthography in Zambia". In African languages: proceedings of the meeting of experts on the transcription and harmonization of African languages, Niamey (Niger), 17-21 July 1978, 164-175. Paris: UNESCO. Available online at $<\mathrm{http}$ :/ unesdoc.unesco.org/images/0003/000333/033385EB.pdf>. Accessed on 22.09.2019.

Lands and Mines, Ministry of (1966) Gazetteer of geographical names in the Republic of Zambia. Lusaka: Government Printers.

Lisimba, Mukumbuta (2000) Lozi names in language and culture. Libreville: International Centre for Bantu Civilizations.

NA $2004=$ Names Act of Estonia [English translation]. Available online at $<$ https: $/ /$ www.riigiteataja.ee/en/eli/ee/Riigikogu/act/524032015006/consolide>. Accessed on 06.09.2019.

Ngulube, Naboth M. J. (1989) Some aspects of growing up in Zambia. Lusaka: Nalinga Consultancy and Sol Consult A/S Limited.

NRAZ = The National Registration Act of Zambia . Available online at $<\mathrm{http}: /$ www. parliament.gov.zm/sites/default/files/documents/acts/National\%20Registration\%20 Act.pdf $>$. Accessed on 15.08.2019.

Penda, Chanda (2013) Encyclopedia of Zambian names: reconciling Zambian and global worldviews. Lusaka: Pensulo Publishers Limited.

PNA 1996 = Place Names Act of Estonia [English translation]. Available online at $<$ https://www.riigiteataja.ee/en/eli/ee/529052014008/consolide $>$. Accessed on 06.09.2019.

Tembo, Mwizenge (2006) Zambian traditional names: the meaning of Tumbuka, Chewa, Nsenga, Ngoni and Tonga names, Lusaka: Julubbi Enterprises Limited.

UNGEGN website $=$ United Nations group of experts on geographical names (UNGEGN). Available online at $<\mathrm{https}$ ://unstats.un.org/unsd/ungegn/>. Accessed on 22.09.2019.

Whiteman, Tanya D. (2008) Vocabulary instruction for English language learners in grades three through five: a multivocal synthesis. Reno: University of Nevada. 
Kokkuvõte. Osward Chanda ja Peeter Päll: Nimekorraldus Sambias ja Eestis: võrdlev analüüs. Artikkel vaatleb Sambia ja Eesti nimesituatsiooni erinevusi ja sarnasusi. Sambia on mitmekeelne maa, ametikeel on inglise; Eesti on ametlikult ükskeelne maa, praktikas käibivad eesti keele kõrval ka vene ja inglise keel. Sambia isikunimedes on perekonnanimed valdavalt kohalikku päritolu, eesnimed enamjaolt euroopalikud; kohanimed on valdavalt ühekordsed. Sambias ei ole erinevalt Eestist nimeseadusi isiku- ja kohanimede reguleerimiseks. Ühine on mõlema maa puhul asjaolu, et ajaloos on varem domineerinud võõrvõimud, mis on jätnud jälje nimepilti. Kui proovida sõnastada universaalseid nimekorralduspõhimõtteid, siis võiksid need olla 1) nimede kui kultuuripärandi kaitse; 2) kohalike nimekujude eelistamine; 3) nimede keeleline korrektsus, 4) oma kultuuriidentiteedi hoidmine, 5) nimede pragmaatiliste aspektide (eristatavus, nimeinfo kättesaadavus jm) arvestamine.

Märksõnad: onomastika, nimed, nimekorraldus, Sambia, Eesti 